\title{
Neuroprotective potential of erythropoietin in neonates; design of a randomized trial
}

\author{
Sandra E. Juul ${ }^{1 *}$, Dennis E. Mayock', Bryan A. Comstock ${ }^{2}$ and Patrick J. Heagerty ${ }^{2}$
}

\begin{abstract}
Background: In 2013, nearly four million babies were born in the U.S., among whom 447,875 were born preterm. Approximately 30,000 of these infants were born before 28 weeks of gestation. These infants, termed Extremely Low Gestational Age Neonates (ELGANs), experience high morbidity and mortality despite modern therapies: approximately $20 \%$ of ELGANs admitted to an NICU die before discharge, $20 \%$ of survivors have severe, and $20 \%$ moderate neurodevelopmental impairment (NDI). New approaches are needed to improve neonatal outcomes. Recombinant erythropoietin (Epo) is a promising neuroprotective agent that is widely available, affordable, and has been used safely in neonates to stimulate erythropoiesis. There are extensive preclinical data to support its use as a neuroprotective intervention: Epo promotes normal brain maturation by increasing neurogenesis, angiogenesis, and by protecting oligodendrocytes. Epo also decreases acute brain injury following hypoxia ischemia by decreasing inflammation, oxidative and excitotoxic injury, resulting in decreased apoptosis. Despite the availability of both preclinical and safety data there has not been a definitive clinical evaluation of the benefit of Epo, and a large phase III trial is necessary to provide evidence to support potential changes in practice guidelines.

Findings: We first review the preclinical data motivating further clinical trials, and then describe in detail the design of the PENUT study (Preterm Epo Neuroprotection). PENUT is a phase III study evaluating the effect of neonatal Epo treatment on the combined outcome of death or severe NDI among ELGANS. 940 subjects will be randomized to determine: 1) whether Epo decreases the combined outcome of death or NDI at 22-26 months corrected age; 2) the safety of high dose Epo administration to ELGANs; 3) whether Epo treatment decreases serial measures of circulating inflammatory mediators, and improves biomarkers of brain injury; and 4) whether Epo treatment improves brain structure at 36 weeks postmenstrual age as measured by MRI.
\end{abstract}

Conclusions: Epo neuroprotection is an exciting new approach to preterm neuroprotection, and if efficacious, will provide a much-needed therapy for this group of vulnerable infants.

Keywords: Prematurity, Neuroprotection, ELGANS, Biomarkers

\section{Introduction}

Extremely Low Gestational Age Neonates (ELGANs) are at high risk of death or neurodevelopmental impairment (NDI). Data from 9575 ELGANs born between 2003 and 2007 and admitted to Neonatal Research Network intensive care units showed that death or NDI occurred in 91, 80, 66 and $56 \%$ of those born at 24, 25, 26 and 27 weeks gestation, respectively [1]. These sobering statistics do not include infants that died before admission to a NICU, or those who died within $12 \mathrm{~h}$ of admission. Major neurologic morbidities, which include cerebral

\footnotetext{
* Correspondence: sjuul@uw.edu

'Department of Pediatrics, Division of Neonatology, University of

Washington, 1959 Pacific Ave NE, Box 356320, Seattle, WA 98195-6320, USA

Full list of author information is available at the end of the article
}

palsy $(\mathrm{CP})$, deafness, blindness, and cognitive disabilities, are present in up to $50 \%$ of surviving extremely preterm infants at school age [2-7]. In addition to the traditional measures of impairment, long-term follow-up studies are now also increasingly identifying behavioral dysfunctions such as attention deficit disorder and autism spectrum disorder [8-11]. Sequelae of extreme prematurity are a tremendous burden to the individuals, their families, and to our health care system, accounting for nearly half of the health care dollars spent on newborn care [12]. Clearly, a neuroprotective intervention that improves outcomes for ELGANs would be profoundly beneficial to the individual, the family and to society [13].

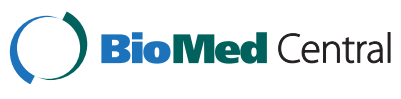

(c) 2015 Juul et al. Open Access This article is distributed under the terms of the Creative Commons Attribution 4.0 International License (http://creativecommons.org/licenses/by/4.0/), which permits unrestricted use, distribution, and reproduction in any medium, provided you give appropriate credit to the original author(s) and the source, provide a link to the Creative Commons license, and indicate if changes were made. The Creative Commons Public Domain Dedication waiver (http://creativecommons.org/publicdomain/zero/1.0/) applies to the data made available in this article, unless otherwise stated. 


\section{Findings}

A phase III study to test the safety and efficacy of high dose Epo is indicated, based on current preliminarypreclinical and clinical data.

The PENUT (Preterm Epo Neuroprotection) Trial is a randomized, placebo controlled, double blind study ofEpo neuroprotection in an ELGAN population.

\section{Review}

\section{Vulnerabilities of the preterm brain}

ELGANs are born at a time when the fetal brain is rapidly increasing in size, shape and complexity $[14,15]$. Brain development is vulnerable to interruption by hypoxiaischemia, oxidant stress, inflammation, and excitotoxicity, as evidenced by structural, biochemical, and cell-specific injury $[16,17]$. Oligodendrocytes, which emerge and mature between 24 and 32 weeks of development, are particularly susceptible to injury, resulting in the white matter injury (WMI) characteristic of preterm infants [18]. Although the transition from fetal to early postnatal life is the period of greatest vulnerability [19], ELGANs remain at risk for brain injury throughout the period of oligodendrocyte development.

Perinatal inflammation (chorioamnionitis, necrotizing enterocolitis, or sepsis) is associated with increased risk of NDI $[2,20,21]$. Microglial activation [22] and increased cytokine expression, particularly TNF- $\alpha$, interleukin (IL)-6, and IL-8, have been associated with brain injury in preterm infants $[23,24]$ and in animal models of neonatal brain injury [25].

\section{Epo neuroprotection}

Epo has anti-inflammatory, anti-excitotoxic, anti-oxidant, and anti-apoptotic effects on neurons and oligodendrocytes, and promotes neurogenesis and angiogenesis, which are essential for repair of injury and normal neurodevelopment [26-30]. Epo effects are dose-dependent, and multiple doses are more effective than single doses [31-33]. Epo reduces neuronal loss and learning impairment following brain injury [34]. Even when initiated as late as $48-72 \mathrm{~h}$ after injury, there is evidence of improved behavioral outcomes, enhanced neurogenesis, increased axonal sprouting, and reduced white matter injury $[35,36]$. Epo has demonstrated anti-inflammatory effects, which may contribute to neuroprotection in the scenario of preterm birth and increased inflammatory activity [37-43]. Epo also stimulates growth factors required for normal brain growth such as brain-derived neurotrophic factor (BDNF) and glial cell derived neurotrophic factor (GDNF) [27, 44].

Epo decreases WMI in adult and neonatal animal models of brain injury [35, 45-50]. Preliminary work in preterm infants suggests this holds true for developing human brain [51]. This protective effect may be mediated by the effect of Epo on oligodendrocytes: Epo promotes the proliferation, maturation and differentiation these cells [52], and protects them from injury induced by interferon- $\gamma$, LPS, and hypoxic-ischemia $[35,53,54]$.
In addition to cell specific effects in brain, Epo increases iron utilization as erythropoiesis is increased. Iron is highly reactive and normally sequestered by transport proteins. Unbound iron produces free radicals and subsequent oxidative injury. Preterm infants have measurable free iron, which increases after transfusions of red blood cells or during metabolic instability such as sepsis $[55,56]$. Epo may contribute to neuroprotection by decreasing free iron.

\section{Epo dosing}

In rodent, ovine and nonhuman primate models of neonatal brain injury, repeated Epo doses of 1000-5000 U/kg/dose result in sustained neuroprotection, improving both short and long-term structure and function [31, 32, 49, 57-59]. Higher doses are needed for neuroprotection than for erythropoiesis, due to the low percentage of circulating Epo that crosses the blood brain barrier [60]. In acute models of brain injury, including a late dose (7 days post injury) significantly improves outcomes [32, 61]. Preclinical data suggest that Epo neuroprotection has a U-shaped dosing curve, with too little or too much Epo resulting in diminished efficacy [31, 62]. To estimate how neuroprotective Epo doses in rat pups relate to human pharmacokinetics, plasma Epo concentrations were measured in extremely low birth weight infants (<1000 g birth weight) after 500, 1000, and $2500 \mathrm{U} / \mathrm{kg} /$ dose [63]. Nonlinear kinetics were noted, consistent with previous studies in neonates [64]. In these infants, intravenous administration of 500 and $1000 \mathrm{U} / \mathrm{kg}$ resulted in similar peak concentrations but faster clearance than were achieved in rat pups after $5000 \mathrm{U} / \mathrm{kg}$ (Fig. 1). Doses of $1000 \mathrm{U} / \mathrm{kg}$ Epo resulted in area under the curve (AUC) measurements most similar to the most protective dose in rats [31]. The $500 \mathrm{U} /$ $\mathrm{kg}$ dose fell short (one third to one quarter the protective AUC), while $2500 \mathrm{U} / \mathrm{kg}$ was close to three times the optimal dose in rats. Minimum steady-state concentrations (mean = $576 \mathrm{mU} / \mathrm{ml}$ ) were produced using the $1000 \mathrm{U} / \mathrm{kg} / \mathrm{dose}$. Thus, we estimate that multiple doses of $1000 \mathrm{U} / \mathrm{kg}$ would be safe and achieve neuroprotective circulating concentrations in human neonates.

\section{Translational trials of neonatal Epo neuroprotection for preterm infants are in progress}

Enrollment in a randomized, double masked phase II trial of Epo neuroprotection for preterm infants has been completed (NCT00413946). 443 infants (gestational age 26 0/ 7-31 6/7 weeks) were randomized to Epo (3000 U/kg, $N=$ $229)$ or saline $(N=214)$ at $3,12-18$, and $36-42 \mathrm{~h}$ after birth. This dose and dosing regimen was found to be safe [65], and those treated with Epo showed improved white matter integrity $[51,66]$. Long term follow up is ongoing.

Two additional preliminary reports of preterm infants treated prospectively show benefit: 1$)$ Preterm infants 500 to $1250 \mathrm{~g}$ treated with either Epo (400 U/kg 3x/ 


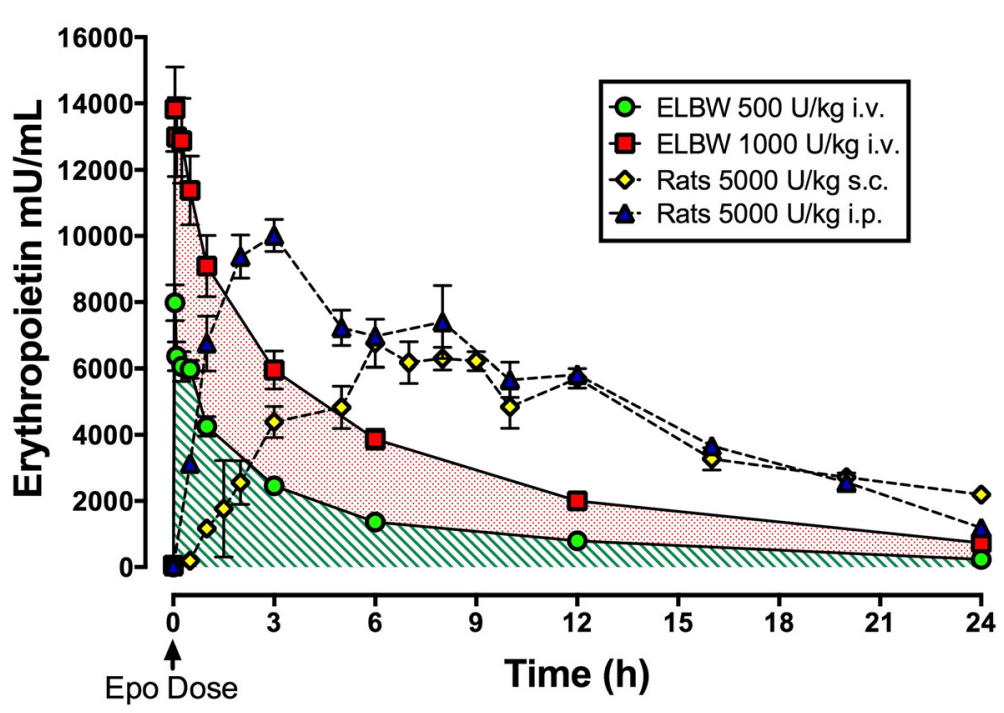

Fig. 1 Epo pharmacokinetics in neonatal rats compared to extremely low birth weight infants (ELBW). Epo concentration in $\mathrm{mU} / \mathrm{mL}$ is shown on the $Y$ axis, and time in hours on the $X$ axis. Serum concentration in neonatal rats is shown following subcutaneous injection (s.c.) or intraperitoneal injection (i.p.) of $5000 \mathrm{U} / \mathrm{kg} /$ dose of Epo. This is compared to dosing in human ELBW infants with $500 \mathrm{U} / \mathrm{kg} / \mathrm{dose}$ or $1000 \mathrm{U} / \mathrm{kg} / \mathrm{dose}$ by intravenous injection (i.v.). The area under the curve (AUC) of $1000 \mathrm{U} / \mathrm{kg} /$ dose most closely approximates the neuroprotective concentrations noted in rats treated with $5000 \mathrm{U} / \mathrm{kg} / \mathrm{dose}$

week, $N=29)$ or Darbepoetin $(10 \mathrm{U} / \mathrm{kg} /$ dose once a week, $N=27$ ) from birth to 35 weeks postmenstrual age (PMA) had an average cumulative cognitive score 8 to 10 points higher than placebo/controls with Epo-treated infants earning scores of $97.9 \pm 14$, and Darbepoetin-treated infants scoring $96.2 \pm 7.3$ compared to $88 \pm 14$ for controls $(N=24)$. Epo recipients also performed statistically better than controls on object permanence testing [67]. The combined scores for NDI or death were significantly better in both Epo and Darbepoetin treated groups, with combined scores of $15.5 \%$ compared to $48.2 \%$ in the control group. 2) Follow-up of ELBW infants that received 500 to $2500 \mathrm{U} / \mathrm{kg}$ Epo x 3 doses in a phase I/II trial [63] showed that Epo treatment correlated with improvement of cognitive $(R=.22, p<0.05)$ and motor $(R=.15, p<0.05)$ scores [68].

\section{Risks of intervention}

In adults, complications of prolonged Epo treatment include polycythemia, seizures, hypertension, stroke, myocardial infarction, congestive heart failure, tumor progression, and shortened time to death. None of these adverse effects have been reported in Epo-treated neonates in over 3000 patients enrolled in randomized controlled trials [69]. Epo trials in neonates for the purposes of testing its erythropoietic effect have shown it to be a safe drug for use in this population. There is robust data from preclinical animal work showing that Epo, when used at optimal doses (1000-5000 U/kg), shows short and long term improvement in brain injury that approximates 50-80 \%, and no safety issues have been discovered. Even the risk of retinopathy of prematurity (ROP) has not been substantiated in randomized controlled trials [70, 71]. Safety data for high dose Epo (3000 U/kg x 3 doses) have recently been published [65]. However, as yet unknown rare complications may occur, so safety data must still be collected as studies of Epo neuroprotection are done.

The PENUT (Preterm Epo Neuroprotection) Trial is a randomized, placebo controlled, double blind study of Epo neuroprotection in an ELGAN population. Figure 2 provides an overview of the study. 940 patients will be enrolled at 19 sites across the United States in order to evaluate 752 infants at 22-26 months corrected age. Enrollment and initial treatment with study drug will occur by $24 \mathrm{~h}$ after birth. Subjects will be randomized to either Epo treatment or placebo, and treatment will continue until 32-6/7 weeks PMA. Short term, intermediate and long-term safety measures will be determined by comparing Epo-treated and control infants. Mechanisms of Epo neuroprotection and potential biomarkers of outcome will be sought by measuring sequential inflammatory cytokines and markers of brain injury. In a subset of subjects, a brain MRI will be done at 36 weeks PMA to determine whether Epo treatment preserves brain growth and decreases injury. After discharge from the hospital, phone contact will be made at 4 to 6 month intervals. Data will be collected on interval medical history and functional status. In- person follow-up will occur at two years corrected age (22-26 months), at which time standardized neurodevelopmental assessments will be made. The primary outcome is death or severe 


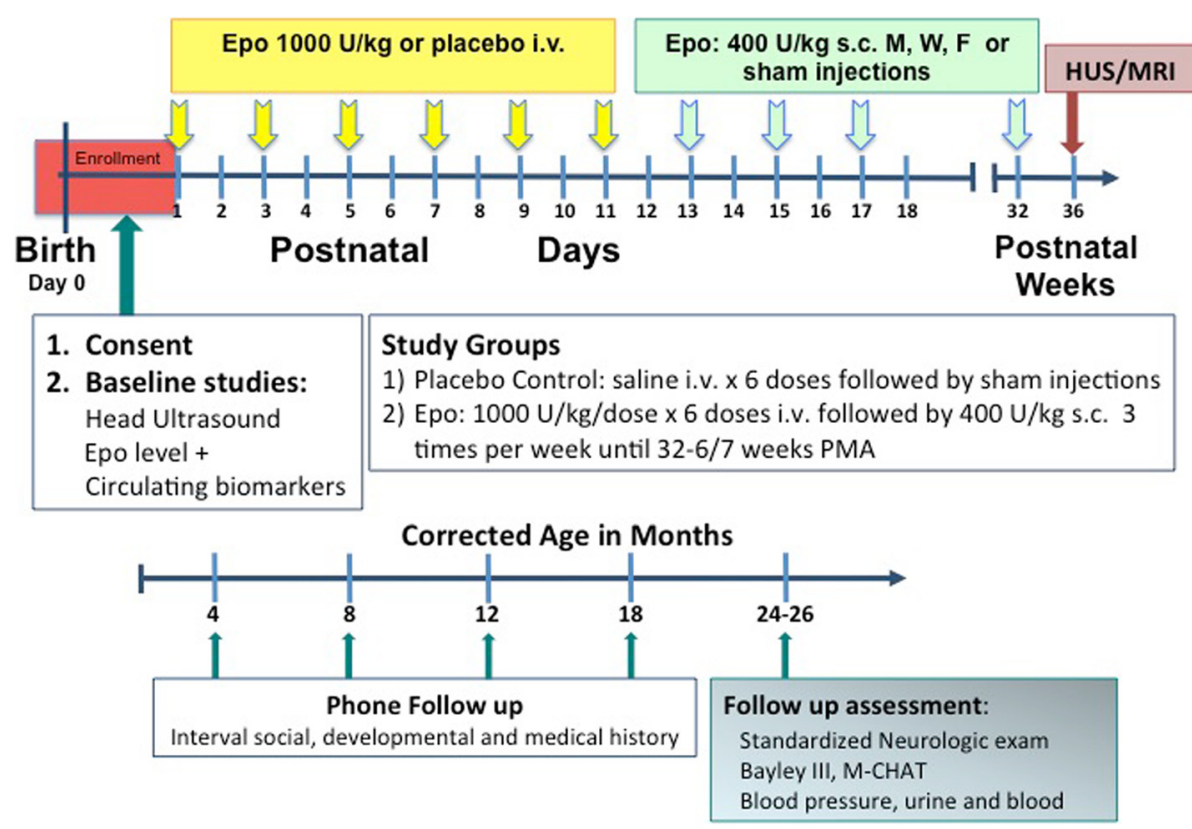

Fig. 2 PENUT Trial Overview. Significant events each subject will undergo when participating in the PENUT trial

NDI at 22-26 months corrected age, with a secondary outcome of death, severe or moderate NDI. This study of high dose Epo for the purposes of neuroprotection of preterm infants is registered with the FDA (IND \# 12656) and ClinicalTrials.gov (NCT01378273).

\section{Eligibility and enrollment}

Patients will be eligible if they are NICU inpatients between 24-0/7 and 27-6/7 weeks of gestation and less than $24 \mathrm{~h}$ of age with arterial or venous access. Parental consent may be obtained prenatally or postnatally, as dictated by each recruitment site's IRB. Patients will be excluded if there are known major life-threatening anomalies, known or suspected chromosomal anomalies, severe hematologic crises such as disseminated intravascular coagulopathy, twin-twin transfusion such that 1 twin is not eligible due to polycythemia or hydrops, polycythemia (hematocrit $>65 \%$ ), hydrops fetalis, or known congenital infection such as toxoplasmosis, CMV, rubella or syphilis.

\section{Randomization}

We will use block randomization within site using variable blocks of size 4 to 10 subjects. Using block randomization ensures that equal numbers of subjects are randomized to the intervention and control arm and that the two groups are balanced at period enrollment intervals. For multiple births (twins, triplets, etc.), all infants will be randomized to the same treatment group (e.g. effective randomization of the mother). Randomization sequences will be provided to the research pharmacy at each site. Randomization will be stratified on site, gestational age category (24-25 weeks, 26-27 weeks), and on multiple gestation (number of babies carried to birth: singleton, twins, triplets, or more).

\section{Epo dose justification}

The Epo dose, and duration of therapy chosen for this study is based upon available preclinical and clinical data for Epo neuroprotection. Although doses as high as $3000 \mathrm{U} / \mathrm{kg} / \mathrm{dose}$ are being tested in preterm infants without apparent adverse effects [65], we chose 1000 $\mathrm{U} / \mathrm{kg} /$ dose based on our phase I/II data [63]. We will treat with high dose during the first weeks of life when physiologic vulnerability is highest, followed by maintenance Epo through 32 weeks postmenstrual age (the period of oligodendrocyte vulnerability).

\section{Iron supplementation}

Maintaining iron sufficiency in a growing preterm infant is important for normal brain growth. Because of this, iron guidelines were established for the PENUT trial. When enteral feedings are started, a standard iron containing formula is used if breast milk is unavailable. Once infants (all subjects) reach an enteral intake of $60 \mathrm{~mL} / \mathrm{kg} / \mathrm{d}$ and are at least one week old, they are started on enteral iron at a dose of $3 \mathrm{mg} / \mathrm{kg} / \mathrm{d}$ total. Enteral iron is increased to $6 \mathrm{mg} / \mathrm{kg} / \mathrm{d}$ when infants achieve an enteral intake of 100 to $120 \mathrm{~mL} / \mathrm{kg} / \mathrm{d}$ [72]. Serum ferritin or $\mathrm{ZnPP} / \mathrm{H}$ ratios are checked at 14 and 42 days, and iron adjusted accordingly. If subjects are not able to tolerate enteral feedings and oral iron supplements, they 
will be given maintenance iron parenterally $(3 \mathrm{mg} / \mathrm{kg} /$ week, adjusted based on iron indices).

\section{Study procedures}

Five $0.5 \mathrm{~mL}$ blood samples will be drawn from each enrolled subject on the following schedule: prior to the first study drug dose, $30 \mathrm{~min}$ after the 4th study drug dose (peak), $30 \mathrm{~min}$ prior to the 5th study drug dose (trough), on day $14 \pm 1$ day, and at the 22-26 month inperson visit (Fig. 3). These samples will be used to determine circulating Epo concentrations, cytokine measurements, and biomarkers of brain injury. The following inflammatory markers and growth factors will be assayed: BDNF, Interferon-gamma (IFN- $\gamma$ ), IL-1 $\beta$, IL-6, IL-8, IL-10, tumor necrosis factor- $\alpha$ (TNF- $\alpha$ ), transforming growth factor (TGF)- $\beta$, matrix metalloproteinase (MMP)-2 and MMP-9, macrophage inflammatory protein- $1 \alpha$ (MIP-1 $\alpha$ ), MIP-1 $\beta$, monocyte chemotactic protein-1 (MCP-1) and tissue inhibitor of metalloproteinase (TIMP)-1 [50, 73-75]. Markers of neurotoxicity and brain injury will include: S100B, glial fibrillary acidic protein (GFAP), neuron specific enolase (NSE), Tau, Activin A, and Ubiquitin C-terminal hydrolase-L1 (UCH-L1) [76-78].

Brain magnetic resonance imaging (MRI) will be obtained on 110 subjects from each study arm at 36 weeks PMA (220 total). All scans will be done on $3 \mathrm{~T}$ scanners using an optimized, standardized protocol. MRI's will be evaluated centrally, and analysis will include both quantitative [79, 80] and qualitative evaluations [81].

\section{Outcomes}

The primary outcome variable is the composite outcome of death or neurodevelopmental impairment at 22-26 months. All personnel involved in the neurodevelopmental assessments will undergo standardized training, and will be blind to study treatment. Assessment at 22-26 months corrected age will include: Bayley III Scales of Infant and Toddler Development, a standardized neurological examination, Gross Motor Function Classification System (GMFCS) assessment, the Child Behavior Checklist, and the Modified Checklist for Autism in Toddlers (MCHAT-R). Neurodevelopmental impairment (NDI) is defined as the presence of any one of the following: $\mathrm{CP}$, Bayley III cognitive or motor scale $<70$. There is a known inflation of scores from the Bayley II to III [82-84] and we will therefore also consider a threshold of $<85$ for secondary analysis. Cerebral palsy will be categorized based on features present on standardized neurologic exam, and classified as mild, moderate, or severe, with hemiplegia or diplegia. Two stepped outcomes will be used: the primary outcome is very stringent, and uses a cut off of two standard deviations below the mean for cognitive or motor scales $(<70)$. The secondary outcome uses a cut off of one standard deviation below the mean for these criteria $(<85)$, which will still have a significant impact on the child, family, and healthcare system. The 2-year assessment will provide a window into early language development and early gross- and fine-motor development. We plan to submit further grant applications for long-term follow-up at 5 years of age, which correlates better with ultimate function [85].

\section{Power and sample size for primary outcome}

In order to determine the necessary sample size for efficacy evaluation, we formulated assumptions for the primary outcome rate in the treated and untreated groups. The primary outcome measure is the rate of death or severe NDI. Using data from two sources, we computed the expected rates of death or NDI for the neonates that we will enroll. The Vermont Oxford Network 2008 Follow-up Report [86] evaluated the disability status of infants born in 2008 only, and the combined 2004-2008 cohorts. Follow-up status was determined at age 18-24 months and information regarding death and NDI is provided for subgroups of children based on their gestational age. Therefore, we used these data to forecast expected trial results for our eligible subjects (24-27 weeks gestational age). In order to estimate the overall rate observed among treated neonates we have assumed that there will be no effect of treatment on death, but

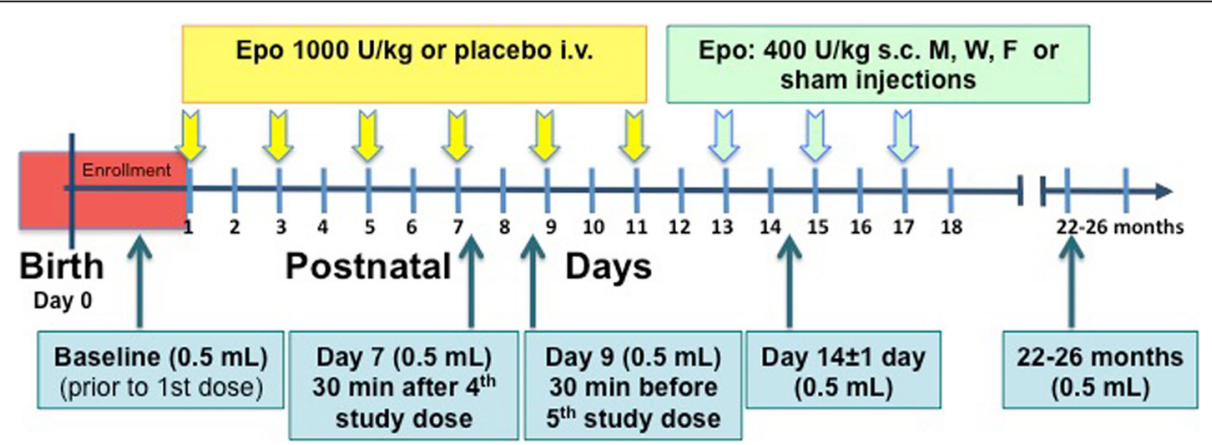

Fig. 3 PENUT Trial Blood Draws. The timing of all PENUT related blood draws is shown schematically 
that Epo will lead to a decrease in the rate of NDI. If we assume a multiplicative reduction in the NDI rate of 0.45 then we expect a treated NDI rate of $12 \%$ and an overall rate of death + NDI of $30.4 \%$ as compared to the control rate of $40.4 \%$. Therefore, in order to obtain a target sample size we assumed: an overall control rate of $40 \%$, and an overall treated rate of $30 \%$ corresponding to an overall treatment rate ratio of 0.75 . Using the control and treated rates of $40 \%$ and $30 \%$ respectively leads to a sample size of 376 evaluated subjects per arm or a total evaluated sample size of 752 subjects in order to have $80 \%$ power. We inflated the sample size by $20 \%$ to account for correlation among multiple births (clustering) and potential loss to follow-up to arrive at a total enrollment target of 940 subjects.

\section{Statistical analysis}

A modified intent-to-treat (ITT) approach will be used [87], with all randomized infants who receive the first dose of study treatment included in the analysis. All pre-specified hypotheses will be tested using a two-sided type I error of 0.05 with no formal adjustment for multiple comparisons unless otherwise specified (such as with safety outcomes). Secondary analyses that focus on separate hypotheses will not require correction for multiple comparisons, but those analyses that use multivariate measures such as multiple brain image parameters would be corrected for multiple comparisons using standard methods.

Given that we anticipate enrollment of multiple births we require that all analyses properly account for the within-sibship correlation of outcomes. We will use Generalized Estimating Equations (GEE), which is a versatile regression approach for the analysis of discrete and continuous outcomes [88]. Use of "robust" standard errors will provide valid statistical inference and fully account for the clustering of data.

\section{Data and safety monitoring}

A data safety monitoring board (DSMB) created by National Institute of Neurological Disorders and Stroke (NINDS) will review the accruing data to ensure that the study is adequately enrolling and to ensure that there are no serious safety concerns. The research coordinators at each site monitor each subject daily for the presence of any complications. Serious adverse events are brought to the attention of an independent Medical Monitor, the DSMB, and IRB in writing. A potential risk that is unique to preterm infants is the risk of ROP [89]. In the published studies of preterm neonates receiving potentially neuroprotective doses of Epo, no difference has been noted between treatment and control groups [63, 90-92]. The DSMB will conduct formal interim safety monitoring analysis at approximately 25 , 50 , and $75 \%$ and $100 \%$ of target enrollment of $n=940$ using O'Brien-Fleming [93] boundaries for death (net alpha $=0.05$ ) and 10 serious adverse events (Bonferroni corrected alpha $=0.005)$.

\section{Discussion}

Ample preclinical, and growing phase I and II data support the neuroprotective effects of Epo as an approach to improving the neurologic outcomes of ELGANS. In designing the PENUT Trial, we considered the issue of what constitutes a clinically significant effect size. Characteristics of trials that lead to changes in clinical practice include: the estimated magnitude of benefit; the number of subjects studied; and the risk of the therapy. Ibrahim et al. performed a 13-item web-based questionnaire asking 226 neonatologists what would convince them to adopt a new therapy in infants $<28$ weeks of gestation. The survey assumed no adverse results of treatment. The survey results suggest that a reduction of Bayley scores $<80$ by $25 \%$ of subjects would change behavior in $40 \%$ of clinicians, while the same change in $50 \%$ of subjects would persuade two thirds of neonatologists to adopt the intervention. A sample size of 200 per arm resulted in one third of neonatologists changing their behavior, while a sample size of 400 per arm resulted in two thirds changing behavior. The PENUT study is powered to detect a $45 \%$ reduction in NDI, with a large enough sample size to be judged of sufficient quality to change practice for $64 \%$ of clinicians surveyed [personal communication]. Epo neuroprotection is an exciting new approach to preterm neuroprotection, and if efficacious, will provide a much-needed therapy for this group of vulnerable infants.

\section{Conclusion}

Current neuroprotective strategies include prenatal steroids, magnesium sulfate, delayed cord clamping, postnatal caffeine, breast milk, and avoiding postnatal growth retardation. Despite these measures, outcomes of extreme prematurity have not improved significantly over the last decades, with survivors remaining at significant risk of neurodevelopmental impairment. Erythropoietin has great potential to improve these outcomes. There is ample preclinical data showing beneficial effects of Epo on brain injury. Clinical trials to determine whether these preclinical findings translate to clinical improvement are ongoing.

\section{Competing interests}

The authors declare that they have no competing interests.

\section{Authors' contributions}

All authors have made significant and substantial contributions to this review and to the conception, design and acquisition of data for the PENUT Trial. SJ wrote the first draft of this manuscript, and is the principal investigator of the PENUT Trial. DM contributed to the design and execution of the PENUT Trial and provided editing of the review. $\mathrm{BC}$ and $\mathrm{PH}$ provided all of the statistical design of the PENUT trial and developed a portal for the acquisition of data for the PENUT trial. They also edited this review. All authors read and approved the final manuscript. 


\section{Acknowledgements}

We thank Stephanie Hauge MS, for her considerable contributions to organization and smooth running of the PENUT trial, to Todd Richards PhD, Colin Studholme PhD, Dennis Shaw MD, and Christopher Traudt MD for their development of the imaging aspects of this study, and to Michael O'Shea MD, Karl Kuban MD and Jean Lowe MD for their input into the follow up aspects of the study.

\section{Funding}

S Juul: NINDS U01NS077953, NICHD R01HD073128, NICHD R21NS093154-01, NIDDK R01DK103608

D Mayock: NINDS U01NS077953, Thrasher Research Fund 30002250-1401 AM01, NHLBI U01-HL-094338

B Comstock: NINDS U01NS077955, AHRQ R01HS22972, NIAMS

UH3AT0007766, NHGRI U01HG006507

P Heagerty: NINDS U01NS077955, NHLBI R01HL072966, NCI P01CA053996,

PCORI R-D2C-1310-07253, NIDDK R01DK103608, NIMH UH2MH106338, AHRQ R01HS22972, NHGRI U01HG006507, NIAMS UH3AT0007766, NCATS UL1TR000423

\section{Author details}

${ }^{1}$ Department of Pediatrics, Division of Neonatology, University of Washington, 1959 Pacific Ave NE, Box 356320, Seattle, WA 98195-6320, USA. ${ }^{2}$ Department of Biostatistics, University of Washington, 4333 Brooklyn Avenue NE, Box 359461, Seattle, WA 98195-9461, USA.

\section{Received: 24 July 2015 Accepted: 26 October 2015} Published online: 02 December 2015

\section{References}

1. Stoll BJ, Hansen NI, Bell EF, Shankaran S, Laptook AR, Walsh MC, et al. Neonatal outcomes of extremely preterm infants from the NICHD Neonatal Research Network. Pediatrics. 2010;126(3):443-56. doi:10.1542/peds.2009-2959.

2. Hintz SR, Kendrick DE, Stoll BJ, Vohr BR, Fanaroff AA, Donovan EF, et al. Neurodevelopmental and growth outcomes of extremely low birth weight infants after necrotizing enterocolitis. Pediatrics. 2005;115(3):696-703. doi:10.1542/peds.2004-0569.

3. Beauchamp MH, Thompson DK, Howard K, Doyle LW, Egan GF, Inder TE, et al. Preterm infant hippocampal volumes correlate with later working memory deficits. Brain. 2008;131(Pt 11):2986-94. doi:10.1093/brain/awn227.

4. Edgin JO, Inder TE, Anderson PJ, Hood KM, Clark CA, Woodward LJ. Executive functioning in preschool children born very preterm: relationship with early white matter pathology. J Int Neuropsychol Soc. 2008;14(1):90-101.

5. Gargus RA, Vohr BR, Tyson JE, High P, Higgins RD, Wrage LA, et al. Unimpaired outcomes for extremely low birth weight infants at 18 to 22 months. Pediatrics. 2009;124(1):112-21. doi:10.1542/peds.2008-2742.

6. Ancel PY, Goffinet F, Group E-W, Kuhn P, Langer B, Matis J, et al. Survival and Morbidity of Preterm Children Born at 22 Through 34 Weeks' Gestation in France in 2011: Results of the EPIPAGE-2 Cohort Study. JAMA Pediatr. 2015;169(3):230-8. doi:10.1001/jamapediatrics.2014.3351.

7. Ancel PY, Livinec F, Larroque B, Marret S, Arnaud C, Pierrat V, et al. Cerebral palsy among very preterm children in relation to gestational age and neonatal ultrasound abnormalities: the EPIPAGE cohort study. Pediatrics. 2006;117(3):828-35. doi:10.1542/peds.2005-0091.

8. Johnson S, Hollis C, Kochhar P, Hennessy E, Wolke D, Marlow N. Autism spectrum disorders in extremely preterm children. J Pediatr. 2010;156(4):525-31. doi:10.1016/.jpeds.2009.10.041.

9. Buchmayer S, Johansson S, Johansson A, Hultman CM, Sparen P, Cnattingius S. Can association between preterm birth and autism be explained by maternal or neonatal morbidity? Pediatrics. 2009;124(5):e817-25. doi:10.1542/peds.2008-3582.

10. Kuban KC, O'Shea TM, Allred EN, Tager-Flusberg H, Goldstein DJ, Leviton A. Positive screening on the Modified Checklist for Autism in Toddlers (M-CHAT) in extremely low gestational age newborns. J Pediatr. 2009;154(4):535-40. doi:10.1016/j.jpeds.2008.10.011

11. Scott MN, Taylor HG, Fristad MA, Klein N, Espy KA, Minich N, et al. Behavior Disorders in Extremely Preterm/Extremely Low Birth Weight Children in Kindergarten. J Dev Behav Pediatr. 2012. doi:10.1097/DBP.0b013e3182475287.

12. Petrou S, Abangma G, Johnson S, Wolke D, Marlow N. Costs and health utilities associated with extremely preterm birth: evidence from the EPICure study. Value Health. 2009;12(8):1124-34. doi:10.1111/j.1524-4733.2009.00580.x.
13. Petrou S, Johnson S, Wolke D, Marlow N. The association between neurodevelopmental disability and economic outcomes during midchildhood. Child: care, health and development. 2012. doi:10.1111/ j.1365-2214.2012.01368.x.

14. Lodygensky GA, Vasung L, Sizonenko SV, Huppi PS. Neuroimaging of cortical development and brain connectivity in human newborns and animal models. J Anat. 2010;217(4):418-28. doi:10.1111/j.1469-7580.2010.01280.x.

15. Huppi PS. Growth and development of the brain and impact on cognitive outcomes. Nestle Nutr Workshop Ser Pediatr Program. 2010;65:137-49. doi:10.1159/000281156. discussion 49-51.

16. Volpe JJ. Brain injury in premature infants: a complex amalgam of destructive and developmental disturbances. Lancet Neurol. 2009;8(1):110-24. doi:10.1016/S1474-4422(08)70294-1.

17. Volpe JJ. Systemic inflammation, oligodendroglial maturation, and the encephalopathy of prematurity. Ann Neurol. 2011;70(4):525-9. doi:10.1002/ana.22533.

18. Back SA, Riddle A, McClure MM. Maturation-dependent vulnerability of perinatal white matter in premature birth. Stroke. 2007;38(2 Suppl):724-30.

19. Volpe JJ. Neurology of the Newborn. 4th ed. Philadelphia, Pennsylvania: W.B. Saunders; 2001. p. 435-437.

20. Martin CR, Dammann O, Allred EN, Patel S, O'Shea TM, Kuban KC, et al. Neurodevelopment of extremely preterm infants who had necrotizing enterocolitis with or without late bacteremia. J Pediatr. 2010;157(5):751-6. doi:10.1016/j.jpeds.2010.05.042. e1.

21. Leviton A, Fichorova R, Yamamoto Y, Allred EN, Dammann O, Hecht J, et al. Inflammation-related proteins in the blood of extremely low gestational age newborns. The contribution of inflammation to the appearance of developmental regulation. Cytokine. 2011;53(1):66-73. doi:10.1016/j.cyto.2010.09.003.

22. Ivacko JA, Sun R, Silverstein FS. Hypoxic-ischemic brain injury induces an acute microglial reaction in perinatal rats. Pediatr Res. 1996;39(1):39-47.

23. Foster-Barber A, Dickens B, Ferriero DM. Human perinatal asphyxia: correlation of neonatal cytokines with MRI and outcome. Dev Neurosci. 2001;23(3):213-8.

24. Bartha Al, Foster-Barber A, Miller SP, Vigneron DB, Glidden DV, Barkovich AJ, et al. Neonatal encephalopathy: association of cytokines with MR spectroscopy and outcome. Pediatr Res. 2004;56(6):960-6.

25. Juul S, Felderhoff-Mueser U. Epo and other hematopoietic factors. Semin Fetal Neonatal Med. 2007;12(4):250-8. doi:10.1016/j.siny.2007.01.015.

26. Kumral A, Gonenc S, Acikgoz O, Sonmez A, Genc K, Yilmaz O, et al. Erythropoietin increases glutathione peroxidase enzyme activity and decreases lipid peroxidation levels in hypoxic-ischemic brain injury in neonatal rats. Biol Neonate. 2005;87(1):15-8.

27. Wang L, Zhang Z, Wang Y, Zhang R, Chopp M. Treatment of stroke with erythropoietin enhances neurogenesis and angiogenesis and improves neurological function in rats. Stroke. 2004;35(7):1732-7.

28. Iwai M, Cao G, Yin W, Stetler RA, Liu J, Chen J. Erythropoietin promotes neuronal replacement through revascularization and neurogenesis after neonatal hypoxia/ischemia in rats. Stroke. 2007;38:2795-803.

29. Shingo T, Sorokan ST, Shimazaki T, Weiss S. Erythropoietin regulates the in vitro and in vivo production of neuronal progenitors by mammalian forebrain neural stem cells. J Neurosci. 2001;21(24):9733-43.

30. Osredkar D, Sall JW, Bickler PE, Ferriero DM. Erythropoietin promotes hippocampal neurogenesis in in vitro models of neonatal stroke. Neurobiol Dis. 2010;38(2):259-65. doi:10.1016/j.nbd.2010.01.015.

31. Kellert BA, McPherson RJ, Juul SE. A comparison of high-dose recombinant erythropoietin treatment regimens in brain-injured neonatal rats. Pediatr Res. 2007;61(4):451-5. doi:10.1203/pdr.0b013e3180332cec.

32. Gonzalez FF, Abel R, Almli CR, Mu D, Wendland M, Ferriero DM. Erythropoietin sustains cognitive function and brain volume after neonatal stroke. Dev Neurosci. 2009;31(5):403-11. doi:10.1159/000232558.

33. Gonzalez FF, McQuillen P, Mu D, Chang Y, Wendland M, Vexler Z, et al. Erythropoietin enhances long-term neuroprotection and neurogenesis in neonatal stroke. Dev Neurosci. 2007;29:321-30.

34. Demers EJ, McPherson RJ, Juul SE. Erythropoietin protects dopaminergic neurons and improves neurobehavioral outcomes in juvenile rats after neonatal hypoxia-ischemia. Pediatr Res. 2005;58(2):297-301. doi:10.1203/01.PDR.0000169971.64558.5A.

35. Iwai M, Stetler RA, Xing J, Hu X, Gao Y, Zhang W, et al. Enhanced oligodendrogenesis and recovery of neurological function by erythropoietin after neonatal hypoxic/ischemic brain injury. Stroke. 2010;41(5):1032-7. doi:10.1161/STROKEAHA.109.570325. 
36. Reitmeir R, Kilic E, Kilic U, Bacigaluppi M, ElAli A, Salani G, et al. Post-acute delivery of erythropoietin induces stroke recovery by promoting perilesional tissue remodelling and contralesional pyramidal tract plasticity. Brain. 2011;134(Pt 1):84-99. doi:10.1093/brain/awq344.

37. Gorio A, Gokmen N, Erbayraktar S, Yilmaz O, Madaschi L, Cichetti C, et al. Recombinant human erythropoietin counteracts secondary injury and markedly enhances neurological recovery from experimental spinal cord trauma. PNAS. 2002:99(14):9450-5. doi:10.1073/pnas.142287899.

38. Villa P, Bigini P, Mennini T, Agnello D, Laragione T, Cagnotto A, et al. Erythropoietin selectively attenuates cytokine production and inflammation in cerebral ischemia by targeting neuronal apoptosis. J Exp Med. 2003;198(6):971-5. doi:10.1084/jem.20021067.

39. Sun Y, Calvert JW, Zhang JH. Neonatal hypoxia/ischemia is associated with decreased inflammatory mediators after erythropoietin administration. Stroke. 2005;36(8):1672-8.

40. Siren AL, Fratelli M, Brines M, Goemans C, Casagrande S, Lewczuk P, et al. Erythropoietin prevents neuronal apoptosis after cerebral ischemia and metabolic stress. PNAS. 2001;98(7):4044-9.

41. Bian XX, Yuan XS, Qi CP. Effect of recombinant human erythropoietin on serum S100B protein and interleukin-6 levels after traumatic brain injury in the rat. Neurol Med Chir (Tokyo). 2010;50(5):361-6.

42. Juul SE, Beyer RP, Bammler TK, McPherson RJ, Wilkerson J, Farin FM. Microarray analysis of high-dose recombinant erythropoietin treatment of unilateral brain injury in neonatal mouse hippocampus. Pediatr Res. 2009;65(5):485-92. doi:10.1203/PDR.0b013e31819d90c8.

43. Yatsiv I, Grigoriadis N, Simeonidou C, Stahel PF, Schmidt OI, Alexandrovitch AG, et al. Erythropoietin is neuroprotective, improves functional recovery, and reduces neuronal apoptosis and inflammation in a rodent model of experimental closed head injury. FASEB J. 2005;19(12):1701-3.

44. Dzietko M, Felderhoff-Mueser U, Sifringer M, Krutz B, Bittigau P, Thor F, et al. Erythropoietin protects the developing brain against N-methyl-D-aspartate receptor antagonist neurotoxicity. Neurobiol Dis. 2004;15(2):177-87. doi:10.1016/j.nbd.2003.10.006

45. Vitellaro-Zuccarello L, Mazzetti S, Madaschi L, Bosisio P, Fontana E, Gorio A, et al. Chronic erythropoietin-mediated effects on the expression of astrocyte markers in a rat model of contusive spinal cord injury. Neuroscience. 2008;151(2):452-66.

46. Li L, Jiang Q, Ding G, Zhang L, Zhang ZG, Li Q, et al. MRI identification of white matter reorganization enhanced by erythropoietin treatment in a rat model of focal ischemia. Stroke. 2009;40(3):936-41. doi:10.1161/STROKEAHA.108.527713.

47. Zhang L, Chopp M, Zhang RL, Wang L, Zhang J, Wang Y, et al. Erythropoietin amplifies stroke-induced oligodendrogenesis in the rat. PLOS ONE. 2010;5(6), e11016. doi:10.1371/journal.pone.0011016.

48. Yamada M, Burke C, Colditz P, Johnson DW, Gobe GC. Erythropoietin protects against apoptosis and increases expression of non-neuronal cell markers in the hypoxia-injured developing brain. J Pathol. 2011. doi:10.1002/path.2862.

49. Rees S, Hale N, De Matteo R, Cardamone L, Tolcos M, Loeliger M, et al. Erythropoietin is neuroprotective in a preterm ovine model of endotoxininduced brain injury. J Neuropathol Exp Neurol. 2010;69(3):306-19. doi:10.1097/NEN.0b013e3181d27138.

50. Savino C, Pedotti R, Baggi F, Ubiali F, Gallo B, Nava S, et al. Delayed administration of erythropoietin and its non-erythropoietic derivatives ameliorates chronic murine autoimmune encephalomyelitis. J Neuroimmunol. 2006;172(1-2):27-37. doi:10.1016/j.jneuroim.2005.10.016.

51. Leuchter RH, Gui L, Poncet A, Hagmann C, Lodygensky GA, Martin E, et al. Association between early administration of high-dose erythropoietin in preterm infants and brain MRI abnormality at term-equivalent age. JAMA. 2014;312(8):817-24. doi:10.1001/jama.2014.9645.

52. Sugawa M, Sakurai Y, Ishikawa-leda Y, Suzuki H, Asou H. Effects of erythropoietin on glial cell development; oligodendrocyte maturation and astrocyte proliferation. Neurosci Res. 2002:44(4):391-403.

53. Genc K, Genc S, Baskin H, Semin I. Erythropoietin decreases cytotoxicity and nitric oxide formation induced by inflammatory stimuli in rat oligodendrocytes. Physiol Res. 2006;55(1):33-8.

54. Mizuno K, Hida H, Masuda T, Nishino H, Togari H. Pretreatment with low doses of erythropoietin ameliorates brain damage in periventricular leukomalacia by targeting late oligodendrocyte progenitors: a rat model. Neonatology. 2008;94(4):255-66. doi:10.1159/000151644
55. Buonocore G, Perrone S, Longini M, Paffetti P, Vezzosi P, Gatti MG, et al. Non protein bound iron as early predictive marker of neonatal brain damage. Brain. 2003;126(Pt 5):1224-30

56. Ozment CP, Turi JL. Iron overload following red blood cell transfusion and its impact on disease severity. Biochim Biophys Acta. 2009;1790(7):694-701. doi:10.1016/j.bbagen.2008.09.010.

57. Loeliger MM, Mackintosh A, De Matteo R, Harding R, Rees SM. Erythropoietin protects the developing retina in an ovine model of endotoxin-induced retinal injury. Invest Ophthalmol Vis Sci. 2011;52(5):2656-61. doi:10.1167/iovs.10-6455.

58. van der Kooij MA, Groenendaal F, Kavelaars A, Heijnen CJ, van Bel F. Neuroprotective properties and mechanisms of erythropoietin in in vitro and in vivo experimental models for hypoxia/ischemia. Brain Res Rev. 2008:59(1):22-33.

59. Traudt CM, McPherson RJ, Bauer LA, Richards TL, Burbacher TM, McAdams RM, et al. Concurrent erythropoietin and hypothermia treatment improve outcomes in a term nonhuman primate model of perinatal asphyxia. Dev Neurosci. 2013;35(6):491-503. doi:10.1159/000355460.

60. Juul SE, McPherson RJ, Farrell FX, Jolliffe L, Ness DJ, Gleason CA. Erytropoietin concentrations in cerebrospinal fluid of nonhuman primates and fetal sheep following high-dose recombinant erythropoietin. Biol Neonate. 2004;85(2):138-44.

61. Gonzalez FF, Larpthaveesarp A, McQuillen P, Derugin N, Wendland M, Spadafora $\mathrm{R}$, et al. Erythropoietin increases neurogenesis and oligodendrogliosis of subventricular zone precursor cells after neonatal stroke. Stroke. 2013:44(3):753-8. doi:10.1161/STROKEAHA.111.000104.

62. Weber A, Dzietko M, Berns M, Felderhoff-Mueser U, Heinemann U, Maier RF, et al. Neuronal damage after moderate hypoxia and erythropoietin. Neurobiol Dis. 2005:20(2):594-600

63. Juul SE, McPherson RJ, Bauer LA, Ledbetter KJ, Gleason CA, Mayock DE. A phase I/II trial of high-dose erythropoietin in extremely low birth weight infants: pharmacokinetics and safety. Pediatrics. 2008;122(2):383-91.

64. Widness JA, Veng-Pedersen P, Peters C, Pereira LM, Schmidt RL, Lowe LS. Erythropoietin pharmacokinetics in premature infants: developmental, nonlinearity, and treatment effects. J Appl Physiol. 1996;80(1):140-8.

65. Fauchere JC, Koller BM, Tschopp A, Dame C, Ruegger C, Bucher HU, et al. Safety of Early High-Dose Recombinant Erythropoietin for Neuroprotection in Very Preterm Infants. J Pediatr. 2015;167(1):52-7. doi:10.1016/j.jpeds.2015.02.052. e3.

66. O'Gorman RL, Bucher HU, Held U, Koller BM, Huppi PS, Hagmann CF, et al. Tract-based spatial statistics to assess the neuroprotective effect of early erythropoietin on white matter development in preterm infants. Brain. 2015;138(Pt 2):388-97. doi:10.1093/brain/awu363.

67. Ohls RK, Kamath-Rayne BD, Christensen RD, Wiedmeier SE, Rosenberg A, Fuller J, et al. Cognitive Outcomes of Preterm Infants Randomized to Darbepoetin, Erythropoietin, or Placebo. Pediatrics. 2014. doi:10.1542/peds.2013-4307.

68. McAdams RM, McPherson RJ, Mayock DE, Juul SE. Outcomes of extremely low birth weight infants given early high-dose erythropoietin. J Perinatol. 2013;33(3):226-30. doi:10.1038/jp.2012.78.

69. Juul S. Erythropoietin in anemia of prematurity. J Matern Fetal Neona. 2012;25 Suppl 5:80-4. doi:10.3109/14767058.2012.716987.

70. Ohlsson A, Aher SM. Early erythropoietin for preventing red blood cell transfusion in preterm and/or low birth weight infants. Cochrane Database Syst Rev. 2014;4, CD004863. doi:10.1002/14651858.CD004863.pub4.

71. Ohls RK, Christensen RD, Widness JA, Juul SE. Erythropoiesis Stimulating Agents Demonstrate Safety and Show Promise as Neuroprotective Agents in Neonates. J Pediatr. 2015. doi:10.1016/j.jpeds.2015.03.054.

72. Franz AR, Mihatsch WA, Sander S, Kron M, Pohlandt F. Prospective randomized trial of early versus late enteral iron supplementation in infants with a birth weight of less than 1301 grams. Pediatrics. 2000;106(4):700-6

73. Bednarek N, Svedin P, Garnotel R, Favrais G, Loron G, Schwendiman L, et al. Increased MMP-9 and TIMP-1 in mouse neonatal brain and plasma and in human neonatal plasma after hypoxia-ischemia: a potential marker of neonatal encephalopathy. Pediatr Res. 2012;71(1):63-70. doi:10.1038/pr.2011.3.

74. O'Shea TM, Allred EN, Kuban KC, Dammann O, Paneth N, Fichorova R, et al. Elevated concentrations of inflammation-related proteins in postnatal blood predict severe developmental delay at 2 years of age in extremely preterm infants. The Journal of Pediatrics. 2012;160(3):395-401. doi:10.1016/j.jpeds.2011.08.069. e4.

75. Chen G, Shi JX, Hang CH, Xie W, Liu J, Liu X. Inhibitory effect on cerebral inflammatory agents that accompany traumatic brain injury in a rat model: 
a potential neuroprotective mechanism of recombinant human erythropoietin (rhEPO). Neurosci Lett. 2007;425(3):177-82.

76. Douglas-Escobar M, Yang C, Bennett J, Shuster J, Theriaque D, Leibovici A, et al. A pilot study of novel biomarkers in neonates with hypoxicischemic encephalopathy. Pediatric Research. 2010;68(6):531-6. doi:10.1203/PDR.0b013e3181f85a03.

77. Ehrenreich H, Kastner A, Weissenborn K, Streeter J, Sperling S, Wang KK, et al. Circulating damage marker profiles support a neuroprotective effect of erythropoietin in ischemic stroke patients. Mol Med. 2011;17(11-12):1306-10. doi:10.2119/molmed.2011.00259.

78. Ennen CS, Huisman TA, Savage WJ, Northington FJ, Jennings JM, Everett $A D$, et al. Glial fibrillary acidic protein as a biomarker for neonatal hypoxicischemic encephalopathy treated with whole-body cooling. Am J Obstet Gynecol. 2011;205(3):251 e1-7. doi:10.1016/j.ajog.2011.06.025.

79. Habas PA, Corbett-Detig JM, Kim K, Rousseau F, Glenn OA, Barkovich AJ et al., editors. Global and regional patterns of tissue volume growth in the normal fetal brain from in utero MRI. 16th Annual Meeting of the Organization for Human Brain Mapping; 2010; Barcelona, Spain.

80. Rodriguez-Carranza CE, Mukherjee P, Vigneron D, Barkovich J, Studholme C A framework for in vivo quantification of regional brain folding in premature neonates. Neuroimage. 2008;41(2):462-78. doi:10.1016/..neuroimage.2008.01.008.

81. Kidokoro H, Neil JJ, Inder TE. New MR imaging assessment tool to define brain abnormalities in very preterm infants at term. AJNR Am J Neuroradiol. 2013;34(11):2208-14. doi:10.3174/ajnr.A3521.

82. Moore T, Johnson S, Haider S, Hennessy E, Marlow N. The Bayley-lll cognitive and language scales: how do scores relate to the Bayley II? Arch Dis Child. 2011;96 Suppl 1:A1-100. doi:10.1136/adc.2011.212563.85.

83. Msall ME. Measuring outcomes after extreme prematurity with the Bayley-ll Scales of infant and toddler development: a cautionary tale from Australia. Arch Pediatr Adolesc Med. 2010;164(4):391-3. doi:10.1001/archpediatrics.2010.25.

84. Anderson PJ, De Luca CR, Hutchinson E, Roberts G, Doyle LW. Underestimation of developmental delay by the new Bayley-lll Scale. Arch Pediatr Adolesc Med. 2010;164(4):352-6. doi:10.1001/archpediatrics.2010.20.

85. Johnson S, Wolke D, Hennessy E, Marlow N. Educational outcomes in extremely preterm children: neuropsychological correlates and predictors of attainment. Dev Neuropsychol. 2011;36(1):74-95. doi:10.1080/87565641.2011.540541.

86. Vermont Oxford Network ELBW Follow-up Report Birth Year 2008 All Centers [database on the Internet] Sept 2011. Accessed.

87. Fisher L, Dixon DO, Herson J, Frankowski RK, Hearron MS, Peace KE, et al. Intention to treat in clinical trials. In: Peace KE, editor. Statistical Issues in Drug Research and Development. New York: Marcel Dekker; 1991. p. 331-50.

88. Diggle PJ, Heagerty PJ, Liang KY, Zeger SL. Analysis of Longitudinal Data. Second Edition ed. Oxford University Press; 2002.

89. Ohlsson A, Aher SM. Early erythropoietin for preventing red blood cell transfusion in preterm and/or low birth weight infants. Cochrane Database Syst Rev. 2006;3, CD004863.

90. Fauchere JC, Dame C, Vonthein R, Koller B, Arri S, Wolf M, et al. An approach to using recombinant erythropoietin for neuroprotection in very preterm infants. Pediatrics. 2008;122(2):375-82. doi:10.1542/peds.2007-2591.

91. Bierer R, Peceny MC, Hartenberger CH, Ohls RK. Erythropoietin concentrations and neurodevelopmental outcome in preterm infants. Pediatrics. 2006;118(3):e635-40.

92. Neubauer AP, Voss W, Wachtendorf M, Jungmann T. Erythropoietin improves neurodevelopmental outcome of extremely preterm infants. Ann Neurol. 2010;67(5):657-66. doi:10.1002/ana.21977.

93. O'Brien PC, Fleming TR. A multiple testing procedure for clinical trials. Biometrics. 1979:35(3):549-56.

\section{Submit your next manuscript to BioMed Central and take full advantage of:}

- Convenient online submission

- Thorough peer review

- No space constraints or color figure charges

- Immediate publication on acceptance

- Inclusion in PubMed, CAS, Scopus and Google Scholar

- Research which is freely available for redistribution

Submit your manuscript at www.biomedcentral.com/submit 